\title{
Patrycja Siemiginowska
}

Uniwersytet Jagielloński w Krakowie

Instytut Psychologii Stosowanej

Zakład Psychologii Pracy i Organizacji

30-348 Kraków, ul. Łojasiewicza 4

e-mail: patrycja.siemiginowska@uj.edu.pl

JoANNA WĄTROBA

e-mail:watroba.joanna@gmail.com

\section{RELACJA PRACA-RODZINA, KOMUNIKACJA MAŁŻEŃSKA I ZDROWIE PRACOWNIKÓW ZATRUDNIONYCH W SYSTEMIE ROTUJĄCYM WSTECZ ${ }^{1}$}

\begin{abstract}
Abstrakt. Wśród pracowników zmianowych $(\mathrm{N}=42)$ dużej polskiej firmy produkcyjnej przeprowadzono badania w zakresie powiązań pomiędzy relacją praca-rodzina, komunikacją małżeńską i zdrowiem psychicznym. Wykorzystano Skalę Wzajemnego Wpływu Pracy i Rodziny, Kwestionariusz Komunikacji Małżeńskiej i Partnerskiej oraz GHQ-28. Uzyskane rezultaty wskazują, że: (1) dolegliwości związane ze zdrowiem psychicznym pracowników zmianowych (objawy somatyczne, lęk i bezsenność, dysfunkcja społeczna/zaburzenia funkcjonowania, ostra depresja i ogólny stan zdrowia) mogą być w umiarkowanym stopniu powiązane z konfliktem praca-rodzina; (2) facylitacja rodzina-praca koreluje umiarkowanie z konstruktywnymi stylami komunikacji małżeńskiej (wsparcie i zaangażowanie), natomiast konflikt praca-rodzina koreluje umiarkowanie z destruktywnym stylem komunikacji w diadzie: deprecjacją. Relacja praca-rodzina wiąże się zatem w umiarkowanym stopniu z komunikacją małżeńską i zdrowiem pracowników zmianowych.
\end{abstract}

Słowa kluczowe: konflikt praca-rodzina, facylitacja praca-rodzina, komunikacja małżeńska, zdrowie psychiczne, praca zmianowa.

\section{PRACA I ŻYCIE RODZINNE PRACOWNIKÓW ZMIANOWYCH}

Problem godzenia życia rodzinnego i zawodowego dotyczy właściwie wszystkich osób związanych z rynkiem pracy (Byron, 2005). Jednocześnie pracownicy zmianowi stanowią dość specyficzną grupę, ponieważ organizacja życia

${ }^{1}$ Badania zostały sfinansowane ze środków DSC Uniwersytetu Jagiellońskiego na zadania służące rozwojowi młodych naukowców oraz uczestników studiów doktoranckich w 2016 roku w ramach zadania badawczego: „Relacja praca-rodzina wśród pracowników zmianowych i jej uwarunkowania" (K/DSC/003621). 
rodzinnego tych osób uzależniona jest od systemu, w jakim są zatrudnione i odbiega od społecznie przyjętych pór aktywności, w tym sposobów spędzania wolnego czasu i angażowania się w życie towarzyskie czy działalność w społeczności lokalnej. Wciąż wzrasta liczba pracowników zatrudnionych w niestandardowych systemach organizacji pracy, a zatem odbiegających od systemu 7-9 godzin pracy w porach 7.00-19.00. Tylko 25\% osób zatrudnionych w Europie pracuje w standardowych godzinach, $10 \%$ podlega samozatrudnieniu. Około $17 \%$ populacji Unii Europejskiej pracującej w niestandardowych godzinach jest zatrudnione w systemach pracy zmianowej (Eurofound, 2012).

Według polskiego Kodeksu pracy (art. 128, § 2, pkt 1) praca zmianowa polega na „wykonywaniu pracy według ustalonego rozkładu czasu pracy przewidującego zmianę pory wykonywania pracy po upływie określonej liczby godzin, dni lub tygodni”. W zależności od systemu pracy - może ona również dotyczyć sobót i niedziel (Dz. U. z 2016 r., poz. 1666, 2138, 2255; z 2017 r., poz. 60.962). Gdy zaistnieje taka konieczność (np. ze względu na wymogi technologiczne lub potrzebę świadczenia usług przez całą dobę, jak ma to miejsce w transporcie czy służbie zdrowia), system pracy może także obejmować porę nocną (od 23.00 do 5.00). Systemy pracy mogą bardzo różnić się od siebie w zakresie czasu trwania jednej zmiany (np. 6, 8 lub 12 godzin), liczby zmian jednego rodzaju przypadających po sobie (przeważnie od 1 do 8 ) oraz kierunku rotacji zmian (w przód: np. zmiana poranna, popołudniowa, nocna; lub wstecz: zmiana nocna, popołudniowa, poranna). Systemy szybko rotujące (do 3 zmian jednego rodzaju następujących po sobie) są bardziej rekomendowane niż wolno rotujące (np. 6 zmian jednego rodzaju z rzędu) ze względu na mniejsze ryzyko zaburzenia funkcjonowania cyklu okołodobowego (Czeisler, Moore-Ede, Coleman, 1982; Pokorski, Costa, 1998). Ponadto w badaniach wykazano mniejszą szkodliwość (niższa częstotliwość dolegliwości zdrowotnych) oraz większą satysfakcję pracowników systemów szybko rotujących w przód niż systemów wolno rotujących wstecz (Knauth, Hornberger, 1998).

Pory aktywności pracowników zmianowych mogą znacznie różnić się od tych, w których podejmują aktywność osoby pracujące jedynie w ciągu dnia. Grafik pracy narzuca pory snu, czuwania i odpoczynku, a także podejmowania konkretnych aktywności, np. wywiązywania się z obowiązków domowych, załatwiania spraw w urzędach czy umawiania spotkań towarzyskich. Również czas wolny od pracy może przypadać w innych dniach i godzinach niż u osób, które nie pracują zmianowo (Iskra-Golec, 1998). Taka sytuacja rodzi konieczność synchronizowania życia rodziny $z$ harmonogramem pracy oraz wymaganiami społecznymi, zwłaszcza w przypadku rodzin z małymi dziećmi (np. poprzez potrzebę dostosowania się do godzin otwarcia żłobków, przedszkoli, szkół oraz innych placówek). Może to stanowić ważną przyczynę napięcia i stresu u pracowników zmianowych. 
Praca zmianowa często wiąże się z koniecznością wykonywania obowiązków w sztucznym oświetleniu oraz w warunkach uciążliwych (np. hałas, obciążenie fizyczne, praca z maszynami). Szczególnie pracownicy fizyczni firm produkcyjnych w przemyśle narażeni są na te dodatkowe stresory (Dmochowska, 2015).

Praca w systemie zmianowym, zwłaszcza obejmującym również zmianę nocną, może w dużym stopniu utrudniać realizację roli partnera i rodzica. Wiąże się to $\mathrm{z}$ okresami nieobecności podczas trwania przyjętego, tzw. normalnego rytmu funkcjonowania rodziny. Pracownik zmianowy spędza ze swoją rodziną mniej czasu wieczorami i w weekendy i w konsekwencji bywa mniej zaangażowany w opiekę nad dziećmi i ich wychowanie czy podejmowanie decyzji dotyczących rodziny i funkcjonowania gospodarstwa domowego. Praca zmianowa wpływa na zmniejszenie częstości kontaktów seksualnych między partnerami oraz może powodować obniżenie poczucia satysfakcji ze związku i rodzić poczucie niemożności zapobiegania sytuacjom konfliktowym (Iskra-Golec, 1998).

Zatrudnienie $\mathrm{w}$ systemie zmianowym nie musi wiązać się jedynie $\mathrm{z}$ trudnościami. Przeciwnie, może ułatwiać wywiązywanie się z części obowiązków domowych poprzez wykorzystanie niektórych pór dnia na realizację części zadań, na przykład aktywne skorzystanie z godzin przedpołudniowych w przypadku zmiany popołudniowej, czy popołudniowych - w przypadku zmiany nocnej. Praca w godzinach popołudniowych lub nocnych umożliwia uzyskanie wolnych przedpołudni, które dają szansę na załatwianie spraw, na które w innym przypadku trzeba by było wziąć dzień wolny (np. wizyty w urzędach), dlatego wielu spośród pracowników zmianowych dostrzega benefity bycia zatrudnionym w systemach rotacyjnych. Ponadto małżonek, który pracuje w systemie zmianowym, może w dniach wolnych przypadających w środku tygodnia zajmować się domem i dziećmi, gdy partner jest w pracy. Wielu pracowników zmianowych docenia ten aspekt swojego harmonogramu (Iskra-Golec, 1998). System pracy może znacząco wpływać na jakość oraz wydajność funkcjonowania rodzin, a utrzymywanie równowagi pomiędzy sferami życia rodzinnego i zawodowego umożliwia odczuwanie zadowolenia z życia i może dawać poczucie spełnienia (Carroll i in., 2013).

\section{KOMUNIKACJA MAŁŻEŃSKA}

Optymalne wzorce komunikowania się opierają się na przekazywaniu jednoznacznych informacji, okazywaniu szacunku parterowi oraz dążeniu do wyjaśnienia różnic między stanowiskami uczestników interakcji. W takim sposobie porozumiewania się ważna jest nie tylko ekspresja własnego punktu widzenia i swoich odczuć, ale także dążenie do tego, by również partner je ujawniał (Grzesiuk, 1994). W intymnym związku zachodzi konieczność porozumiewania się zarówno w sprawach ważnych, jak i prozaicznych. Komunikacja służy budowaniu intymności 
i wpływa na jakość związku - jej funkcja nie jest zatem ograniczona do przekazywania informacji (Kaźmierczak, Plopa, 2012). Jednocześnie w bliskich związkach pojawiają się okresowo konflikty, a członkowie rodzin nieraz narażeni są na sytuacje stresowe. Pod wpływem stresu u mężczyzn występują niekorzystne wzorce zachowań komunikacyjnych (niższe wsparcie i zaangażowanie, większa skłonność do zachowań deprecjonujących). Plopa interpretuje wsparcie w komunikacji jako przejawianą troskę o partnera, zainteresowanie jego problemami i potrzebami, a także szanowanie i docenianie jego wysiłków i starań. Komunikacja oparta na zaangażowaniu zasadza się na tworzeniu atmosfery wzajemnego zrozumienia i bliskości, w której podkreśla się ważność i wyjątkowość partnera. Polega także na wykazywaniu inicjatywy w codziennym dbaniu o rozwój i dynamikę związku, oraz zapobieganiu konfliktom w relacji. Deprecjonujący styl komunikacji wskazuje natomiast na stosowanie agresji wobec partnera, jest używany w celu zdominowania i przejęcia kontroli nad działaniami partnera (Plopa, 2005).

Style komunikacji kobiet i mężczyzn różnią się. Według badań Kaźmierczak i Plopy (2012) kobiety mają tendencję do stosowania krytycznych uwag wobec partnera, jeśli nie spełnia on ich oczekiwań, z kolei mężczyźni wycofują się ze wzajemnych relacji i mogą przejawiać zachowania destrukcyjne dla związku.

Praca zmianowa może nasilać częstość i liczbę konfliktów oraz nieporozumień w wymianie informacji ze względu na ograniczoną obecność partnera zatrudnionego w systemie rotacyjnym. Istnieje zatem ryzyko występowania gorszej komunikacji małżeńskiej w parach, w których przynajmniej jedna osoba pracuje zmianowo. U osób pracujących w systemach zmianowych satysfakcja ze związku oraz poczucie szczęścia i wsparcia ze strony partnera mogą ulec obniżeniu ze względu na sam fakt pracy w systemie rotacyjnym (Iskra-Golec, 1998).

\section{ZDROWIE PRACOWNIKÓW ZMIANOWYCH}

Pracownicy zmianowi charakteryzują się gorszym zdrowiem w porównaniu do osób pracujących jedynie w trybie dziennym (np. Akerstedt, 1998). Towarzyszą im dolegliwości ze strony różnych układów organizmu. Wśród najczęściej zgłaszanych znajdują się: zaburzenia snu (gorsza jakość, mniejsza ilość snu, przewlekły deficyt snu, bezsenność), zaburzenia nerwowe, zaburzenia ze strony układu pokarmowego (obniżenie apetytu lub nadmierny apetyt, choroba wrzodowa, zmiany nowotworowe), zaburzenia ze strony układu krążenia (choroba wieńcowa, zaburzenia sercowo-naczyniowe) oraz spadek odporności organizmu (częstsze przeziębienia) (Pokorski, Costa, 1998). W badaniu 118 pielęgniarek w wieku 20-60 lat w Singapurze stwierdzono częstsze występowanie zaburzeń czynnościowych jelita grubego u kobiet pracujących w systemie zmian rotacyjnych w porównaniu z kobietami zatrudnionymi wyłącznie na zmianach dziennych (odpowiednio: 38\% vs 20\%) (Lu, Gwee, Ho, 2006; Lewandowska, Paradowski, 2008). 
W badaniu przekrojowym 2307 pielęgniarek i 1530 asystentów pielęgniarstwa De Gaudemaris i wsp. (2011) oceniali związek pomiędzy pracą na zmianach nocnych i wysokością ciśnienia tętniczego krwi. Wykazali istotnie wyższe średnie ciśnienie skurczowe krwi u pielęgniarek pracujących na stałych zmianach nocnych niż u pielęgniarek zatrudnionych w systemie stałych zmian dziennych. Pielęgniarki zatrudnione w systemie rotacyjnych zmian miały niższe ciśnienie krwi niż kobiety pracujące w stałych zmianach dziennych (De Gaudemaris i wsp., 2011).

Pracownikom zmianowym nieobce są też zaburzenia działania układu rozrodczego (u kobiet: zaburzenia cyklu miesiączkowego, dłuższe oczekiwanie na pierwsze dziecko, częstsze poronienia, bardziej skomplikowany przebieg ciąży, nasilenie dolegliwości w okresie menopauzy; u mężczyzn: spadek libido, impotencja) oraz zaburzenia endokrynne (zmiany w wydzielaniu melatoniny). $\mathrm{Na}$ przykład w badaniu przekrojowym tajwańskich pielęgniarek (Chung, Yao, Wan, 2005) wykryto, że skrócone cykle menstruacyjne (krótsze niż 25 dni) częściej występują u kobiet zatrudnionych w systemie zmian nocnych (60\%) niż u pielęgniarek pracujących tylko w dzień (10,4\%) lub w systemie rotacyjnym $(21,7 \%)$.

W kontekście zdrowia w literaturze podnosi się także kwestie większej śmiertelności wśród byłych pracowników zmianowych oraz nasilenie procesów starzenia się. Badania nad absencją nie dają jednoznacznych wyników - w niektórych źródłach absencja pracowników zmianowych jest wyższa, w innych nie różni się od absencji pracowników dziennych albo nawet jest niższa (Pokorski, Costa, 1998). Akerstedt (1998) wskazuje na częstsze występowanie problemów sercowo-naczyniowych, kłopotów gastrycznych oraz depresji/obniżonego nastroju u pracowników zmianowych, zaś Shields (2002) u kobiet dodatkowo wskazuje na problemy z zajściem w ciążę oraz częstsze zapadanie na raka piersi. Praca zmianowa obejmująca porę nocną może mieć niekorzystny wpływ na jakość życia, dobrostan psychiczny i zdrowie fizyczne pracowników (Akerstedt, Wright, 2009). Sen, który jest naturalnym sposobem regeneracji i reduktorem zmęczenia u pracowników zmianowych, może nie spełniać swojej funkcji, zwłaszcza jeśli przy pracy nocnej dochodzi do zachwiania równowagi cyklu snu i czuwania (Soldatos, Dikeos, Paparrigopoulos, 2003). Jakość snu osób, które pracują w nocy, jest gorsza, ponadto po zmianie nocnej sypiają w ciągu dnia krócej i łatwiej wybudzają się ze snu, niż ma to miejsce w czasie nocnego wypoczynku (Pokorski, Costa, 1998), co rodzi ryzyko występowania chronicznego zmęczenia.

\section{RELACJA PRACA-RODZINA I JEJ ZNACZENIE DLA KOMUNIKACJI MAŁŻEŃSKIEJ I ZDROWIA}

Popularność teorii roli spowodowała koncentrację dotychczasowych badań wokół negatywnych oddziaływań pomiędzy pracą a życiem rodzinnym (konflikty ról) (Frone, 2002; Greenhaus, Beutell, 1985). Konflikt pomiędzy rolami rodzinnymi 
i związanymi z pracą został określony jako utrudnienie realizacji jednej roli z powodu zaangażowania w drugą. Wyodrębniono dwa kierunki relacji konfliktowej pomiędzy sferami życia rodzinnego i zawodowego: konflikt praca-rodzina, gdy wymagania w pracy utrudniają udział w życiu rodzinnym, oraz konflikt rodzinapraca, gdy obowiązki w rodzinie utrudniają pełnienie roli zawodowej. Rosnąca popularność i rozwój psychologii pozytywnej spowodowały zainteresowanie pozytywnymi oddziaływaniami w tych obszarach życia. W badaniach rozpatrywano różne rodzaje pozytywnych relacji: wzbogacanie, ułatwianie, facylitację - terminy te odnoszą się do sytuacji, gdy pełnienie jednej roli staje się łatwiejsze lub lepsze w związku z pełnieniem innej roli (Aryee i in., 2005; Grzywacz, Marks, 2000; Wayne i in., 2004). Oddziaływanie to również może przebiegać w dwóch kierunkach: facylitacja rodzina-praca oraz facylitacja praca-rodzina.

Badania Josepha Grzywacza i Nadine Marks (2000) pokazały, że emocjonalna bliskość ze współmałżonkiem i dobre relacje w rodzinie mają pozytywny wpływ na relację praca-rodzina. Natomiast niezgoda i konflikty między partnerami wiążą się z negatywną relacją praca-rodzina. Jakość relacji rodzinnych, zaangażowanie w nie i wsparcie bliskich, może być moderatorem stresu, np. w pracy (Grzywacz, Marks, 2000) czy w chorobie (Schokker i in., 2010). Z kolei style komunikacyjne $\mathrm{w}$ rodzinie, jakość bliskich relacji i dopasowanie pomiędzy systemem pracy a systemem rodzinnym mają znaczenie dla sposobu funkcjonowania i poczucia satysfakcji z życia pracowników oraz członków ich rodzin. Początek badań nad tym problemem na świecie sięga lat 80 . XX wieku, ale dopiero niedawno na skutek przemian gospodarczo-społecznych tematyka ta zaczęła wzbudzać duże zainteresowanie w Polsce (Lachowska, 2008).

Demerouti i in. (2004) wskazują, że konflikt praca-rodzina jest u osób pracujących zmianowo wyższy niż u osób pracujących tylko w porze dziennej. Ponadto stosowanie rotacyjnych systemów zmianowych wpływało negatywnie na postawy wobec pracy (satysfakcję z pracy, efektywność zawodową). Aby zmniejszyć natężenie konfliktu praca-rodzina, autorzy rekomendują zminimalizowanie pracy w systemach rotacyjnych, zwłaszcza obejmujących weekendy, oraz zaproponowanie pracownikom jak najbardziej zindywidualizowanych systemów ustalania grafików i elastycznych godzin pracy. W innych badaniach podłużnych, w próbie 337 par, konflikt praca-rodzina i brak zadowolenia ze związku korelowały z wrogim nastawieniem do otoczenia oraz brakiem umiejętności konstruktywnego porozumiewania się (Matthews i in., 1996, za: Carroll, 2012). Wzajemne, subiektywnie odczuwane wsparcie przez współmałżonków jest jednym z aspektów konstruktywnego porozumiewania się, co potwierdziły także badania, w których wsparcie partnerskie zostało uznane za czynnik zmniejszający skutki negatywnego wpływu pracy na rodzinę (Repetti, 1989). Z kolei w swoich badaniach Kinnunen z zespołem (2006) zwraca uwagę na fakt, że niezadowolenie pracowników w wymiarze rodzinnym, także jeśli chodzi o relacje partnerskie, jest jednym z czynników występowania konfliktu rodzina-praca. Z przeglądu literatury 
wynika, że konstruktywna komunikacja jest zasobem, który para może wykorzystać do sprostania wymaganiom pracy i rodziny (Gottman, 1994). Komunikacja małżeńska ma bezpośredni wpływ na satysfakcję ze związku, natomiast satysfakcja ze związku jest istotnym mediatorem relacji praca-rodzina (Holman, 2001). Emocjonalna bliskość pomiędzy małżonkami wiąże się z pozytywną relacją praca-rodzina, natomiast niezgoda pomiędzy partnerami współwystępuje z negatywnym aspektem relacji praca-rodzina. Z kolei facylitacja praca-rodzina łączyła się z lepszym fizycznym i psychicznym zdrowiem amerykańskich pracowników, zaś facylitacja rodzina-praca z lepszym samopoczuciem psychicznym oraz psychologicznym dobrostanem (Grzywacz, Marks, 2000).

Praca $\mathrm{W}$ systemie zmianowym, praca nocna, obejmująca weekendy oraz w wydłużonych godzinach może oddziaływać negatywnie na zachowanie równowagi pomiędzy sferami pracy i życia pozazawodowego oraz przyczynić się do częstszego zapadania na choroby, zwiększenia absencji oraz spadku motywacji do pracy (np. Gerlach, 2014). Praca w systemach zmianowych wiąże się zatem z ryzykiem powstawania i utrzymywania się konfliktu pomiędzy sferami pracy i rodziny. Konflikty te wiążą się także ze zmniejszonym poczuciem zdrowia oraz wypaleniem zawodowym (np. Iskra-Golec i in, 2014). Warto więc dokładniej zbadać te zjawiska wśród pracowników zmianowych oraz ich związek z funkcjonowaniem osób zatrudnionych w różnych systemach, zarówno w sferze życia społecznego, jak i zawodowego. Ciekawym uzupełnieniem dotychczasowej wiedzy w dziedzinie badań nad relacją praca-życie pozazawodowe wydaje się uzyskanie informacji, czy relacja praca-rodzina $\mathrm{w}$ taki sam sposób wiąże się z komunikacją małżeńską i zdrowiem u pracowników zatrudnionych w systemach rotujących wstecz, jak i w innych systemach zmianowych oraz w porównaniu do osób pracujących jedynie w porze dziennej o ustalonych porach pracy (bez pracy zmianowej).

\section{CEL BADAŃ ORAZ HIPOTEZY}

Najważniejszym celem przedstawionych poniżej badań jest potwierdzenie istnienia związku między relacją praca-rodzina a komunikacją małżeńską oraz częstością występowania dolegliwości zdrowotnych u pracowników zmianowych zatrudnionych $\mathrm{w}$ wolno rotującym wstecz systemie z przedłużonym tygodniem pracy. Na podstawie przytoczonych powyżej wyników badań opisujących zależności relacji praca-dom postawiono następujące hipotezy:

1) Występuje pozytywny związek konfliktu praca-rodzina (a) oraz konfliktu rodzina-praca (b) z częstością objawów zdrowotnych w zakresie zdrowia psychicznego;

2) Występuje pozytywny związek stosowania konstruktywnych stylów komunikacji z facylitacją praca-rodzina (a) i facylitacją rodzina-praca (b) oraz negatywny z konfliktem praca-rodzina (c) i konfliktem rodzina-praca (d); 
3) Występuje pozytywny związek stosowania deprecjonującego stylu komunikacji z konfliktem praca-rodzina (a) i konfliktem rodzina-praca (b) oraz negatywny $z$ facylitacją praca-rodzina (c) i facylitacją rodzina-praca (d).

\section{METODA}

\subsection{Osoby badane}

Prace badawcze przeprowadzono w okresie wrzesień-listopad 2016 roku w miejscu pracy, przed początkiem zmiany roboczej lub podczas przerw w pracy. Arkusze były uzupełniane w obecności badacza indywidualnie lub w bardzo małych grupach (2-, 3-osobowych). W badaniach uczestniczyli pracownicy zmianowi dużej polskiej firmy produkcyjnej w branży spożywczej działającej w województwie małopolskim od lat 90. ubiegłego wieku. W firmie zatrudnionych jest ok. 500 pracowników, w tym ok. 300 pracowników zmianowych, spośród których ok. 200 osób pracuje w systemie zmianowym zawierającym zmiany nocne. Spośród grupy tych właśnie pracowników produkcji w badaniu zgodziło się wziąć udział jedynie 59 osób. Do analiz użyto odpowiedzi udzielone przez 42 osoby (kryteria włączenia obejmowały pozostawanie w związku małżeńskim bądź nieformalnym oraz uzupełnienie wszystkich narzędzi badawczych). 64,3\% badanych stanowiły kobiety. Uczestnicy badania byli w wieku 21-53 lata $(\mathrm{M}=39,4$ lat; $\mathrm{SD}=10,04$ lat) ze stażem pracy od 2 do 37 lat $(\mathrm{M}=15,61$ lat; $\mathrm{SD}=9,85$ lat $)$ oraz stażem pracy zmianowej od 7 miesięcy do 35 lat $(\mathrm{M}=11,99$ lat; $\mathrm{SD}=8,74$ lat $)$. Pracownicy mieszkali głównie w małych miejscowościach (por. tab. 1). Większość osób badanych posiadała wykształcenie zawodowe i średnie, jedynie 7\% - wyższe. 76,2\% respondentów posiadało przynajmniej jedno dziecko na utrzymaniu (średni wiek najmłodszego dziecka: 13,08 lat; SD = 7,19 lat). Badani zajmowali stanowiska: pakowacz $(45,2 \%)$, operator $(45,3 \%)$, kontroler jakości, magazynier, menadżer produkcji $(9,5 \%)$. Osoby badane były zatrudnione w systemie trzyzmianowym z 8-godzinnymi zmianami rotującymi wstecz (poranna: 6.00-14.00; nocna: 22.00-6.00; popołudniowa: 14.00-22.00). Pracownicy mieli jeden dzień wolny w tygodniu (niedzielę), a pozostałe sześć dni pracowali na określonej zmianie jednego rodzaju. System stosowany w tej firmie można określić jako wolno rotujący. Absencja w ciągu ostatniego roku z powodów zdrowotnych w badanej grupie pracowniczej była bardzo niska, mimo wykonywania obowiązków zawodowych w systemie z przedłużonym czasem pracy (pow. 40 godzin pracy w tygodniu, por. tab. 2). Pracownicy mieli niewiele czasu na regenerację po zakończeniu tygodnia pracy (np. po ostatniej zmianie nocnej z soboty na niedzielę mieli jedynie 32 godziny odpoczynku przed rozpoczęciem pracy w poniedziałek na zmianie popołudniowej), co może nieść ryzyko chronicznego zmęczenia. 
Tabela 1. Badani pracownicy zmianowi według miejsca zamieszkania

\begin{tabular}{|l|c|c|}
\hline \multicolumn{1}{|c|}{ Miejsce zamieszkania } & Liczba osób & Odsetek \\
\hline Wieś & 30 & 71,4 \\
\hline Miasto do 50 tys. mieszkańców & 10 & 23,8 \\
\hline Miasto pow. 50 tys. mieszkańców & 2 & 4,8 \\
\hline Ogółem & 42 & 100,0 \\
\hline
\end{tabular}

Źródło: opracowanie własne.

Tabela 2. Absencja w ciągu ostatniego roku u badanych pracowników zmianowych

\begin{tabular}{|l|c|c|}
\hline \multicolumn{1}{|c|}{$\begin{array}{c}\text { Absencja w ostatnim roku } \\
\text { (liczba dni) }\end{array}$} & Liczba osób & Odsetek pracowników \\
\hline 0 & 18 & 42,9 \\
\hline $1-5$ & 6 & 14,3 \\
\hline $6-10$ & 8 & 19,0 \\
\hline $11-20$ & 6 & 14,3 \\
\hline $20<$ & 4 & 9,5 \\
\hline Ogółem & 42 & 100,0 \\
\hline
\end{tabular}

Źródlo: opracowanie własne.

\subsection{Narzędzia badawcze}

W badaniach wykorzystano narzędzia samoopisowe: Skalę Wzajemnego Wpływu Pracy i Rodziny (Grzywacz, Marks, 2000), Kwestionariusz Komunikacji Małżeńskiej i Partnerskiej (KKMiP) (Kaźmierczak, Plopa, 2012) oraz GHQ-28 Goldberga w adaptacji Makowskiej i Merecz (2001).

Skala Wzajemnego Wpływu Pracy i Rodziny (por. Iskra-Golec i in., 2014) składa się z szesnastu pozycji, które pozwalają mierzyć pozytywne (facylitacja) oraz negatywne (konflikt) relacje pomiędzy sferą pracy i rodziny w obu kierunkach. Uzyskuje się zatem wyniki w czterech podskalach: konfliktu praca-rodzina, konfliktu rodzina-praca, facylitacji praca-rodzina oraz facylitacji rodzina-praca. Metoda ta umożliwia uzyskanie pomiaru spostrzeganego przez osoby badane wpływu jednej sfery życia na drugą. Zadaniem badanych jest zaznaczenie częstości występowania sytuacji opisanych w każdej pozycji na pięciostopniowej skali (od 1 - nigdy do 5 -zawsze). Współczynnik alfa Cronbacha narzędzia w badanej próbie wynosi 0,74 .

W Kwestionariuszu Komunikacji Małżeńskiej i Partnerskiej znajdują się trzy podskale służące do pomiaru wyników trzech stylów komunikacji - dwóch 
konstruktywnych: wsparcia i zaangażowania, oraz jednego destruktywnego: deprecjacji. Można także obliczyć wynik ogólny. Zastosowano wersję, w której komunikacja $\mathrm{w}$ diadzie jest opisywana $\mathrm{z}$ perspektywy pracownika zmianowego. Badani mieli za zadanie ustosunkować się do 30 stwierdzeń i ocenić częstość zachowań wobec partnera opisanych w każdym zdaniu (od 1 - nigdy do 5 - zawsze). W badanej próbie współczynnik alfa Cronbacha wynosił 0,79.

W narzędziu do subiektywnego pomiaru zdrowia psychicznego (GHQ) uzyskuje się cztery wyniki w podskalach: A - objawy somatyczne, B - lęk i bezsenność, C - dysfunkcja społeczna/zaburzenia funkcjonowania, D - ostra depresja oraz wynik ogólnego stanu zdrowia psychicznego. Zadaniem badanych było określenie częstości występowania dolegliwości w okresie ostatnich kilku tygodniu w skali opisowej od „w ogóle” do „znacznie gorzej/bardziej niż zwykle”. Zastosowano skalę punktową od 0 do 3 pkt. Im wyższy wynik w podskali, tym częstsze dolegliwości, a tym samym gorsze samopoczucie psychiczne. Współczynnik alfa Cronbacha metody w badanej próbie wynosił 0,91 .

Dane uzyskane w badaniu zostały poddane analizom z wykorzystaniem bootstrappingu. Statystyki opisowe badanych zmiennych podano w tabeli 3 . Wykonano analizy korelacji.

Tabela 3. Wartości statystyk opisowych zmiennych mierzonych w badaniu $(\mathrm{N}=42)$

\begin{tabular}{|l|c|c|c|c|c|}
\hline \multicolumn{1}{|c|}{ Zmienna } & Średnia & $\begin{array}{c}\text { Przedziały } \\
\text { ufności (95\%) }\end{array}$ & $\begin{array}{c}\text { Odchylenie } \\
\text { standardowe }\end{array}$ & $\begin{array}{c}\text { Minimalna } \\
\text { wartość }\end{array}$ & $\begin{array}{c}\text { Maksymalna } \\
\text { wartość }\end{array}$ \\
\hline Konflikt praca-rodzina & 13,14 & $12,36-14,00$ & 2,75 & 7 & 19 \\
\hline Konflikt rodzina-praca & 10,67 & $9,60-11,64$ & 3,54 & 4 & 17 \\
\hline Facylitacja praca-rodzina & 11,24 & $10,45-12,02$ & 2,64 & 6 & 18 \\
\hline Facylitacja rodzina-praca & 15,02 & $14,21-15,88$ & 2,78 & 9 & 20 \\
\hline Wsparcie & 38,71 & $36,60-41,00$ & 7,54 & 21 & 50 \\
\hline Zaangażowanie & 32,21 & $30,26-34,09$ & 6,66 & 16 & 43 \\
\hline Deprecjacja & 23,95 & $22,26-25,71$ & 5,95 & 12 & 39 \\
\hline Komunikacja & 112,98 & $107,76-118,24$ & 17,90 & 64 & 146 \\
\hline A- objawy somatyczne & 8,07 & $6,95-9,29$ & 4,02 & 1 & 18 \\
\hline B - lęk i bezsenność & 8,52 & $7,31-9,86$ & 4,28 & 2 & 21 \\
\hline $\begin{array}{l}\text { C- dysfunkcja społeczna/ } \\
\text { zaburzenia funkcjonowania }\end{array}$ & 7,45 & $6,69-8,24$ & 2,62 & 0 & 15 \\
\hline D - ostra depresja & 2,21 & $1,52-3,00$ & 2,48 & 0 & 9 \\
\hline Zdrowie & 26,26 & $23,36-29,71$ & 10,59 & 4 & 56 \\
\hline
\end{tabular}

Źródło: opracowanie własne. 
Tabela 4. Współczynniki korelacji między zmiennymi opisującymi relacje praca-rodzina a zmiennymi związanymi z komunikacją małżeńską i zdrowiem $(\mathrm{N}=42)$

(przy wynikach istotnych statystycznie zapisano w nawiasie 95\% przedziały ufności)

\begin{tabular}{|c|c|c|c|c|}
\hline Zmienne & $\begin{array}{c}\text { Konflikt } \\
\text { praca-rodzina }\end{array}$ & $\begin{array}{c}\text { Konflikt } \\
\text { rodzina-praca }\end{array}$ & $\begin{array}{c}\text { Facylitacja } \\
\text { praca-rodzina }\end{array}$ & $\begin{array}{c}\text { Facylitacja } \\
\text { rodzina-praca }\end{array}$ \\
\hline Wsparcie & 0,11 & 0,22 & 0,23 & $\begin{array}{c}0,40^{* *} \\
(0,16-0,61)\end{array}$ \\
\hline Zaangażowanie & 0,11 & 0,23 & 0,17 & $\begin{array}{c}0,36^{*} \\
(0,8-0,6)\end{array}$ \\
\hline Deprecjacja & $\begin{array}{c}0,31^{*} \\
(0,2-0,57)\end{array}$ & $-0,04$ & $-0,11$ & $-0,24$ \\
\hline $\begin{array}{l}\text { Komunikacja } \\
\text { w diadzie }\end{array}$ & $-0,02$ & 0,19 & 0,20 & $\begin{array}{c}0,38^{*} \\
(0,12-0,6)\end{array}$ \\
\hline $\begin{array}{l}\text { A-objawy } \\
\text { somatyczne }\end{array}$ & $\begin{array}{c}0,32^{*} \\
(-0,02-0,66)\end{array}$ & 0,10 & $-0,16$ & 0,16 \\
\hline B - lęk i bezsenność & $\begin{array}{c}0,43^{* *} \\
(0,16-0,67)\end{array}$ & 0,21 & $-0,14$ & 0,06 \\
\hline $\begin{array}{l}\mathrm{C} \text {-dysfunkcja } \\
\text { społeczna/zaburzenia } \\
\text { funkcjonowania }\end{array}$ & $\begin{array}{c}0,41^{* *} \\
(0,12-0,64)\end{array}$ & 0,01 & $-0,29$ & $-0,10$ \\
\hline D - ostra depresja & $\begin{array}{c}0,52^{* * *} \\
(0,26-0,70) \\
\end{array}$ & $-0,03$ & $-0,06$ & $-0,09$ \\
\hline Zdrowie & $\begin{array}{c}0,52^{* * *} \\
(0,29-0,72)\end{array}$ & 0,11 & $-0,20$ & 0,04 \\
\hline
\end{tabular}

${ }^{*}$ Korelacje istotne na poziomie $p<0,05 ;{ }^{* *}$ Korelacje istotne na poziomie $p<0,01 ;{ }^{* * *}$ Korelacje istotne na poziomie $p<0,001$.

Źródło: opracowanie własne.

\subsection{Wyniki}

Uzyskano częściowe potwierdzenie postawionych hipotez. Stwierdzono, że w badanej próbie konflikt praca-rodzina koreluje na umiarkowanym poziomie z częstością objawów świadczących o możliwych zaburzeniach w zakresie zdrowia psychicznego we wszystkich podskalach (objawów somatycznych, lęku i bezsenności, dysfunkcji społecznej/zaburzeń funkcjonowania i ostrej depresji) oraz z wynikiem ogólnym (hipoteza 1a), a także z deprecjonującym stylem komunikacji (hipoteza 3a). Facylitacja praca-rodzina koreluje ujemnie w umiarkowanym stopniu z konstruktywnymi stylami komunikacji (wsparciem, zaangażowaniem) oraz ogólnym wynikiem komunikacji w diadzie (hipoteza 2b) (por. tab. 4). 


\section{DYSKUSJA}

Celem tego badania było potwierdzenie występowania związków pomiędzy relacją praca-rodzina a komunikacją małżeńską oraz zdrowiem pracowników zmianowych pracujących w systemie rotującym wstecz. Wykazano istotne umiarkowane współwystępowanie facylitacji rodzina-praca z komunikacją nastawioną na wsparcie i zaangażowanie w relację oraz konfliktu praca-rodzina $\mathrm{z}$ deprecjonującym stylem komunikacji w badanej próbie pracowników zmianowych - co jest zgodne $z$ doniesieniami z literatury w tym zakresie (Kinnunen i in., 2006; Repetti, 1989). Satysfakcjonujące relacje oraz możliwość wykorzystania zasobów rodzinnych $\mathrm{w}$ pracy wiążą się zatem z konstruktywnym stylem porozumiewania się. Nie jest zaskakujące również stwierdzenie na podstawie niniejszych wyników, że konflikt $\mathrm{w}$ zakresie pełnienia roli pracownika i członka rodziny łączy się z deprecjonującym stylem komunikacji. Stres związany z konfliktowym charakterem tej relacji może współwystępować z tym niekorzystnym wzorcem porozumiewania się (Carroll i in., 2013). Umiarkowany związek pomiędzy konfliktem pracarodzina i częstością objawów świadczących o osłabieniu zdrowia psychicznego jest zgodny $\mathrm{z}$ doniesieniami $\mathrm{z}$ badań na temat zdrowia pracowników zmianowych (Akerstedt, 1998; Iskra-Golec i in., 2014; Pokorski, Costa, 1998). Przy okazji omawiania stanu zdrowia w tej grupie pracowników warto zwrócić uwagę, że absencja zdecydowanej większości osób badanych była bardzo niska (ok. 75\% badanych opuściło w ostatnim roku maksymalnie 10 dni, przy czym ponad $40 \%$ badanych nie opuściło ani jednego dnia pracy). W literaturze dotyczącej zdrowia pracowników zmianowych często mówi się o tym, że osoby o słabszej konstytucji, mające trudności z przystosowaniem się do pracy zmianowej, bardzo szybko z niej rezygnują. Pozostają zatem bardziej odporne jednostki, wykazujące tolerancję pracy zmianowej (Pokorski, Costa, 1998). Niskie wyniki absencji mogą być wyjaśnione tą naturalną selekcją.

Wyniki uzyskane w niniejszym badaniu należy traktować ostrożnie ze względu na niewielką liczebność próby, wynikającą m.in. z chęci uzyskania homogenicznej próby, oraz przekrojowy charakter badań. Możliwości generalizowania tych rezultatów są ograniczone również z uwagi na bardzo specyficzny system zmianowy (rotujący wstecz, trzyzmianowy system z 6 zmianami jednego rodzaju z rzędu) i charakter pracy zmianowej wykonywanej przez pracowników produkcji. Jest to system obciążający fizycznie i psychicznie z powodu kolejności następujących po sobie zmian oraz dużej liczby dni spędzanych na jednej zmianie, co może przyczyniać się do występowania chronicznego zmęczenia i poczucia osłabienia psychicznego, zwłaszcza w kontekście przedłużonego tygodnia pracy. Pracownicy mieli bardzo ograniczony czas na regenerację sił i odpoczynek przed rozpoczęciem kolejnego cyklu zmian. Ze względu na wskazane ograniczenia (mała liczba osób badanych, specyficzna próba pracowników fizycznych w większości pochodzących 
z niewielkich miejscowości oraz szkodliwy system zmianowy) warto rozszerzyć te badania oraz wzbogacić o porównania $\mathrm{z}$ pracownikami zatrudnionymi $\mathrm{w}$ innych systemach zmianowych. Większość badań relacji praca-dom prowadzonych w Polsce dotyczy grupy zawodowej pielęgniarek (specyficzny charakter pracy) lub pracowników systemów rotujących do przodu. Atutem przedstawionych badań jest przedstawienie relacji praca-rodzina u pracowników zatrudnionych w firmie produkcyjnej oraz pracujących w systemie rotującym wstecz.

\section{BIBLIOGRAFIA}

Akerstedt T. (1998). Shift work and disturbed sleep/wakefulness. Sleep Medicine Reviews, 2 (2), $117-128$

Åkerstedt T., Wright K. P. (2009). Sleep loss and fatigue in shift work and shift work disorder. Sleep Medicine Clinics, 4 (2), 257-271

Aryee S., Srinivas E. S., Tan H. H. (2005). Rhythms of life: Antecedents and outcomes of workfamily balance in employed parents. Journal of Applied Psychology, 90 (1), 132-146

Byron K. (2005). A meta-analytic review of work-family conflict and its antecedents. Journal of Vocational Behavior, 67, 169-198

Carroll S. J., Hill E., Yorgason J. B., Larrson J. H, Sandberg J. G. (2013). Couple Communication as a Mediator Between Work-Family Conflict and Marital Satisfaction. W: Marriage and Family Therapy, http://hdl.lib.byu.edu/1877/etd5514 [dostęp 02.28.2013] Diskussionspapier, No. 11. Dissertations, Paper 93.

Czeisler C. A., Moore-Ede M. C., Coleman, R. H. (1982). Rotating shift work schedules that disrupt sleep are improved by applying circadian principles. Science, 30, 217(4558), 460-463

Chung F. F., Yao C. C., Wan G. H. (2005). The associations between menstrual function and life style/working conditions among nurses in Taiwan. Journal of Occupational Health, 47 (2), $149-156$

De Gaudemaris R., Levant A., Ehlinger V., Herin F., Lepage B., Soulat J.-M., Sobaszek A., Kelly-Irving M., Lang T. (2011). Blood pressure and working conditions in hospital nurses and nursing assistants. The ORSOSA study. Archives of Cardiovascular Diseases, 104(2), 97-103

Demerouti E., Guert A. E., Bakker A. B., Eurema M. (2004). The impact of shift work on workhome conflict, job attitudes and health. Ergonomics, 47, 987-1002

Dmochowska H. (red.). (2015). Rocznik statystyczny pracy. Warszawa: Zakład Wydawnictw Statystycznych

Eurofound (2012). Fifth European Working Conditions Survey. Publication Office of the European Union. Luxemburg

Fenwick R., Tausig M. (2001). Scheduling stress: Family and health outcomes of shift work and schedule control. American Behavioral Scientist, 44, 1179-1198

Frone M. (2002). Work-Family Balance. W: J. C. Quick, L. E. Tetrick (eds.) (2002). Handbook of Occupational Health Psychology (s. 143-162). Washington: American Psychological Association

Gerlach R. (2014). Przemiany pracy i ich konsekwencje dla relacji praca-życie pozazawodowe. W: R. Tomaszewska-Lipiec (red.), Relacje praca-życie pozazawodowe droga do zrównoważonego rozwoju (s. 72-93). Bydgoszcz: Wydawnictwo UKW

Gottman J. (1994). Why Marriages Succeed or Fail: And How You Can Make Yours Last. New York: Simon and Schuster 
Grzesiuk L. (1994). Studia nad komunikacja interpersonalna. Warszawa: Pracownia Testów Psychologicznych Polskiego Towarzystwa Psychologicznego

Greenhaus J. H., Beutell N. J. (1985). Sources of conflict between work and family roles. Academy of Management Review, 10, 76-88

Grzywacz J., Marks N. (2000). Reconceptualizing the Work-Family Interface: An Ecological Perspective on the Correlates of Positive and Negative Spill over Between Work and Family. Journal of Occupational Health Psychology, 5 (1), 111-126

Holman A. (2001). 'That's just not acceptable'. Journal of Learning Disabilities, 29 (1), 3-4

Iskra-Golec I. (1998). Życie społeczne i rodzinne pracownika zmianowego. W: I. Iskra-Golec, G. Costa, S. Folkard, T. Marek, J. Pokorski, L. Smith (red.), Stres pracy zmianowej - przyczyny, skutki, strategie przeciwdziałania (s. 129-134). Kraków: Universitas

Iskra-Golec I. M., Osikowska W., Siemiginowska P., Przetacznik J. (2014). Relacja praca/rodzina, wypalenie zawodowe i zdrowie u pracujących na zmiany strażników miejskich. Czasopismo Psychologiczne, 20 (2), 281-292

Kaźmierczak M., Plopa M. (2012). Komunikacja w bliskich zwiazkach. Teoria i metoda badania. Warszawa: VIZJA PRESS \& IT

Kinnunen U., Feldt T., Geuruts S., Pulkkinen L. (2006). Types of work-family interface: Well-being correlates of negative and positive spillover between work and family. Scandinavian Journal of Psychology, 47, 149-162

Knauth P., Hornberger S. (1998). Changes from weekly backward to quicker forward rotating shift systems in the steel industry. International Journal of Industrial Ergonomics, 21, 3-4, 267-273

Kodeks pracy, Ustawa z dn. 26.06.1974 roku z późniejszymi zmianami (Dz. U. z 2016 r., poz. 1666, 2138, 2255; z 2017 r., poz. 60.962)

Lachowska B. (2008). Wzajemne oddziaływania pracy i rodziny - perspektywa konfliktu i facylitacji (raport z badań pilotażowych). W: L. Golińska, B. Dudek (red.), Rodzina i praca z perspektywy wyzwań i zagrożeń (s. 431-444). Łódź: Wydawnictwo Uniwersytetu Łódzkiego

Lewandowska A., Paradowski L. (2008). Zespół jelita drażliwego - jedno schorzenie czy wiele chorób? Uwagi o ewolucji kryteriów diagnostycznych IBS. Gastroenterologia Polska, 15(1), 37-41

Lu W. Z., Gwee K. A., Ho K. Y. (2006). Functional bowel disorders in rotating shift nurses may be related to sleep disturbances. European Journal of Gastroenterology and Hepatology, 18 (6), 623-627

Makowska Z., Merecz D. (2001). Ocena Zdrowia Psychicznego na podstawie badań Kwestionariuszami Davida Goldberga. Podręcznik dla użytkowników Kwestionariuszy GHQ-12 i GHQ-28. Łódź: Oficyna Wydawnicza Instytutu Medycyny Pracy im. Prof. J. Nofera

Plopa M. (2005). Więzi w małżeństwie i rodzinie. Metody badań. Kraków: Oficyna Wydawnicza Impuls

Pokorski J., Costa G. (1998). Wpływ pracy zmianowej na zdrowie. W: I. Iskra-Golec, G. Costa, S. Folkard, T. Marek, J. Pokorski, L. Smith (red.), Stres pracy zmianowej-przyczyny, skutki, strategie przeciwdziałania (s. 75-97). Kraków: Universitas

Repetti L. R. (1989). Effects of Daily Workload on Subsequent Behavior During Marital Interaction: The Roles of Social Withdrawal and Spouse Support, Journal of Personality and Social Psychology, 57 (4), 651-659

Schokker M. C., Links T. P., Luttik M. L., Hagedoorn M. (2010). The association between regulatory focus and distress in patients with a chronic disease: The moderating role of partner support. British Journal of Health Psychology, 15 (1), 63-78

Shields M. (2002). Shift work and health. Health Reports, 13 (4), 11-33

Soldatos C. R., Dikeos D. G., Paparrigopoulos T. J. (2003). The diagnostic validity of the Athens Insomnia Scale. Journal of Psychosomatic Research, 55 (3), 263-267

Wayne J. H., Musica N., Fleeson W. (2004). Considering the role of personality in the work family experience. Journal of Vocational Behavior, 64, 108-130 
Patrycja Siemiginowska, Joanna Wątroba

\title{
WORK-FAMILY INTERFACE, MARITAL COMMUNICATION AND HEALTH AMONG EMPLOYEES WORKING IN BACKWARD ROTATING SYSTEM
}

\begin{abstract}
Shift workers $(\mathrm{N}=42)$ of a large Polish production company took part in the study investigating linkages between work-family interface, marital communication and health. The following instruments were used in the study: the Work-Family Spillover Scale, the Marital Communication Questionnaire and GHQ-28. The obtained results point to a few phenomena: (1) mental health complaints in shift workers (somatic symptoms, anxiety and sleeplessness, social dysfunction, acute depression, and general health) correlate with work-family conflict (Pearson $r$ coefficients: 0.32; $0.43 ; 0.41 ; 0.52 ; 0.52$, respectively); (2) family-work facilitation correlates with constructive styles of marital communication (support, engagement -0.40 and 0.36 , respectively) and work-family conflict presents a moderate correlation with a destructive communication style: depreciation $(\mathrm{r}=0.31)$. Work-family interface is therefore related to marital communication and health of shift workers.
\end{abstract}

Keywords: work-family conflict, work-family facilitation, marital communication, mental health, shift work. 